\title{
PATTERNS AND GENRES - RECENT METHODOLOGY
}

\section{Miloš KUDĚLKA - Vratislava MOŠOVÁ}

Abstract: In our paper, we are focusing on working educational processes. We are inspired by different authors and try to find common features. These features can help teachers without a pedagogical graduation. In part, we are interested in computer based learning.

Key words: microgenre, pedagogical pattern and antipattern, e-learning pattern.

\section{VZORY A ŽÁNRY - METODOLOGIE SOUČASNOSTI}

Resumé: V našem článku se zaměrujeme na výukové postupy, které fungují. Inspirujeme se u různých autorì a snažíme se najít společné rysy, které mohou pomoci zejména těm, kteři učí, a prítom nejsou studovanými učiteli. Nezapomínáme přitom na technologickou podporu výuky.

Klíčová slova: mikrožánr, pedagogický vzor a antivzor, vzor pro e-learning

\section{1 Úvod}

V současné době vedle klasických vyučovacích metod je značně využívána i výuka s podporou výpočetní techniky. Zařazení počítačů do výuky má své pozitivní, ale i negativní stránky a na učiteli je, aby kladných stránek co nejvíce využil a záporné stránky pokud možno potlačil. $\mathrm{K}$ výhodám výuky podporované počítačem patří především snadná dostupnost informací, možnost navázat s učitelem kontakt on-line (to je výhodné $\mathrm{v}$ př́padech, kdy se jedná o jinou než prezenční formu studia), možnost objevovat zákonitostí na základě grafického názoru nebo možnost experimentovat přímo v elektronickém textu (viz [8]).

Vzdělávací proces je komunikace řízená učitelem. Na znalostech, zkušenostech, intuici a pedagogickém umu učitele závisí úspěch celého procesu. Jak však má učitel vést výuku, aby dosáhl co nejvyšší efektivity? V následujícím textu se pokusíme velmi stručně popsat a do jisté míry zobecnit některé známé učební postupy tak, aby byly pochopitelné bez hlubšího studia pedagogických disciplín. Je známým faktem, že člověk s dobrou zkušeností se svými učiteli, s dobrou intuicí a se schopností nad věcmi přemýšlet, může být také vynikajícím učitelem, a to aniž by kdy studoval pedagogiku a související disciplíny. Čím to je? Prostě dělá věci tak, jak je úspěšně dělají i jiní. A používá metody, které fungují.

Důležitým společným rysem dále popisovaného a s výukou nějak souvisejícího výběru metod je to, že každá metoda má své jméno a jistá pravidla. Jméno je důležité pro komunikaci mezi učiteli. Může dobře posloužit např. pro popis hodiny, pokud chce zkušený učitel vysvětlit jednoduše svému mladému kolegovi, jak by vyučovací hodina mohla vypadat. Díky jménům metod můžeme výuku vnímat jako jakýsi model, ve kterém je nastavena úroveň abstrakce nad společně sdílenou znalost a zkušenost. Díky modelu je pak možné poměrně jednoduchým způsobem popsat strukturu celé hodiny. Aby si ale mladý kolega udělal představu o tom, jak má hodina vypadat, musí znát metody, o kterých zkušený kolega mluví. Jak se seznámit s těmito metodami? Existuje jejich seznam? A jsou metody opravdu to, co by se měl např. budoucí učitel učit?

Metodu můžeme chápat jako sdělenou a do jisté míry formalizovanou zkušenost. Nicméně je nutné si uvědomit, že výuková metoda z principu nemusí poskytnout vždy správné výsledky. Je to tím, že na aplikaci se podílejí lidé (studenti a učitel). A každý, kdo někdy učil, může potvrdit, že sebelépe připravená hodina nemusí vyjít, a to prostě proto, že se nic nedaří. Při volbě metody je samozřejmě potřeba brát $\mathrm{v}$ úvahu obsah, který se učí a prostředí, ve kterém se učí. Nejdůležitější je ovšem vědět, zda je tato metoda vhodná pro konkrétní skupinu studentů (např. metodu vyžadující intenzivní komunikaci je obtížné aplikovat ve skupině studentů se špatnými komunikačními schopnostmi). A stejně důležité je, aby tato metoda vyhovovala učiteli. Není nic horšího, než nutit učitele, který má výborné výsledky, ke změně metod jen proto, že ty jeho nejsou moderní.

Př́istupy, které popisujeme v našem článku, pocházejí od lidí, kteři se pohybují v prostředí počítačových technologií. Bývá obvyklé, že čím blíže má člověk k technologiím, tím více 
potřebuje, aby věci, které používá, byly co nejpřesněji strukturovány. Proto jako jeden z klíčových rysů jejich pohledu na věc je poměrně vysoká snaha o formální popis. My považujeme tento popis za důležitý $\mathrm{z}$ důvodu správného pochopení metody. Nicméně metoda se dá za zvládnutou považovat až ve chvíli, kdy ji učitel začne úspěšně používat ve své praxi.

V tomto článku jsou uvedeny ukázky výše zmíněných metod. V první části o pedagogických vzorech vycházíme ze zkušenosti lidí, kteří popisují často a úspěšně používané metody strukturovanou formou v podobě tzv. vzorů. Dále uvádíme př́íklady jak obecných pedagogických vzorů, tak vzorů pro e-learning. Pro odlehčení se zamýšlíme i nad tzv. pedagogickými antivzory, neboli postupy, které se sice také používají, dokonce fungují, ale bohužel negativně. V závěrečné části o mikrožánrech popisujeme souvislost mezi prezenční a on-line výukou tentokrát z pohledu jiné skupiny učitelů.

\section{Pedagogické vzory}

V sedmdesátých letech byly architektem Christopherem Alexandrem formulovány vzory pro řešení úloh $\mathrm{v}$ architektuře. Alexandrova formulace vzoru (viz [1]): „Každý vzor je pravidlo, které vyjadřuje vztah mezi jistou souvislostí, problémem a řešením“.

Obecně lze říci, že vzor je formulován jako popis a zobecnění určité zkušenosti, která vede $\mathrm{k}$ postupu, jak problém řešit (východiskem vzorů je praktická zkušenost, nikoli nápad). Návod řešení pak musí být tak pružný, aby se vzor dal aplikovat opakovaně a aby přitom výsledky nebyly stereotypní. Po formální stránce je vzor stručný text, který popisuje náčrt problému a popis jeho obecného řešení $\mathrm{v}$ konkrétních souvislostech. Vzory zachycují zkušenost odborníků v určité oblasti, umožňují jednoduchou komunikaci mezi odborníky, řeší přirozený a opakovaně se vyskytující problém a obvykle spolu souvisí a navazují na sebe. Je potřeba také zdůraznit, že vzory rozhodně nejsou momentální nápady autora, nějaké triky, popisy jediného způsobu řešení a popisy, které nevnesou shodu mezi odborníky. Na místě je říci, že vzory by neměly nikoho překvapit, dokonce pravý odborník by měl po přečtení vzoru nabýt jistotu, že ,tohle přece zná“.

Vzory se kromě architektury používají i v různých jiných oblastech. Oblíbené jsou zejména v oblasti softwarového inženýrství (viz [6]). Pedagogické vzory původně formulovali lidé právě z této oblasti, kteří se kromě své specializace zabývají také výukou. Vzory popsali takovým způsobem, aby s nimi mohl pracovat člověk, který nedisponuje pedagogickým vzděláním. Mnoho zdrojů lze nalézt na webových stránkách [9].

Jak už jsme se zmínili, je důležitým předpokladem pro popis vzoru jeho formální struktura. Ta je ve většině případů ustálena na položkách jako

- jméno (název vyjadřující přímo nebo zvláštním, mnohdy velmi nápaditým způsobem opisu určení vzoru), problém (stručná charakteristika úlohy, která se řeší),

- souvislosti (oblasti a situace, ve kterých se vzor používá a príznaky, které jsou charakteristické pro použití vzoru),

- řešení (popis obecného prrístupu $\mathrm{k}$ řešení problému a také upozornění na úskalí, které může přinést.

Důležité jsou také př́iklady použití - ukázky aplikace vzoru na konkrétní problém.

Jako př́klady si uved'me zjednodušené popisy několika vzorů, které mohou být použity jak v běžné prezenční výuce, tak některé $\mathrm{z}$ nich i v e-learningové výuce.

\section{Spirála}

Problém: Výuku lze rozdělit do částí, které na sebe logicky navazují a doplňují se. Každá část umožňuje řešit problém na určité úrovni podrobnosti. Vzor je široce použitelný.

Souvislosti: V každé části jsou studenti zatížení nutností pochopit nové vazby a pohledy na problém resp. používat nové nástroje či techniky. Pokud jim ještě přidáme úlohy „z jiného soudku“, ocitají se znovu na začátku.

Řešení: Je potřeba, aby jednotlivé části umožňovaly pracovat na stejném problému a výuka byla podle toho organizována. V každé následujícím kroku se pak řeší stejné úlohy s vyšší úrovní podrobnosti (abstrakce, kompozice). Výhodou je, že studenta nezatěžujeme analýzou a nutností pochopení nového problému.

\section{Opravár̆}

Problém: Ve výuce se řeší praktické úlohy, není ovšem dostatek času na úlohy většího rozsahu.

Souvislosti: Často nutíme studenty realizovat pouze úlohy, které jsou př́liš jednoduché na to, aby pochopili, jaké problémy mohou nastat, až se 
zvětší rozsah úlohy. Setkání s vyřešenou úlohou většího rozsahu může studenty motivovat jiným způsobem

Řešení: Učitel připraví hotové řešení úlohy většího rozsahu, které obsahuje chyby. Studentům popíše co přesně má řešení dělat a ti mají za úkol řešení opravit. Nutností je mít nástroj, který podpoří hledání chyb.

\section{Zkumavka}

Problém: Studenti se ptávají „A co když ...?"“.

Souvislosti: Často je pro učitele jednoduššî odpovědět, ale tím student věc považuje za odbytou a největší pravděpodobností na ni brzy zapomene.

Řešení: Je-li k dispozici prostředí, ve kterém si student může danou věc vyzkoušet, učitel by měl poradit způsob jak a pak jej nechat pracovat.

\section{Vyplň prázdná místa}

Problém: Studenti (zejména začátečníci) chtějí pracovat na složitějších úlohách, ale nemají zatím dostatečné znalosti na vyřešení úlohy.

Souvislosti: Někdy můžeme dosáhnout zajímavých výsledků s relativně malým množstvím zdrojového textu tak, že známe efektivní způsob použití složité techniky nebo technologie, jejiž úplná znalost není u studentů ani očekávána ani požadována.

Řešení: Učitel připraví velmi dobře a čitelně navrženou úlohu (program, proceduru) a některá místa úmyslně vynechá. Po studentech pak vyžaduje doplnění chybějících míst. Musí být přesně specifikováno, co $\mathrm{v}$ uvedených místech chybí. Výborné je, pokud studenti mohou vidět výsledek ihned po dokončení práce.

\section{Vzory pro e-learning}

V širším slova smyslu je e-learning jakékoli využívání elektronických materiálních a didaktických prostředkủ k efektivnímu dosažení vzdělávacího cíle. V užším slova smyslu je e-learning chápán zejména jako vzdělávání, které je podporováno moderními technologiemi a které je realizováno prostřednictvím počítačových sítí - intranetu a zejména Internetu.. V českém prostředí je spojován zejména s řízeným studiem $\mathrm{v}$ rámci LMS. E-learning je možné realizovat $\mathrm{v}$ různých formách.

- Při offline e-learningu není potřeba, aby byl počítač připojen $\mathrm{k}$ Internetu či jiné počítačové síti. Vzdělávání probíhá pomocí studijních textů (viz [7]) a multimediálních programů, které jsou distribuovány prostřednictvím $C D$ nebo DVD ROMů. Někdy je tento způsob vzdělávání slouží jako podpora a doplněk prezenčního vzdělávání. Tehdy se označuje jako blended learning - smíšené vzdělávání.

- Pro online e-learning již potřebujeme připojení $\mathrm{k}$ počítačové síti (lokální či Internet). Zdroj informací je $\mathrm{v}$ tomto př́ípadě uložen v počítačové síti a mohou jej současně využívat libovolné množství studujících. Online e-learning existuje ve dvou základních podobách: synchronní (komunikace mezi tutory a studujícími probíhá v reálném čase. Proto v daném okamžiku musí být přítomni jak tutoři, tak studující. Ke komunikaci pak používají různých nástrojů jako audio, video konference, chat, ...) a asynchronní (současná př́tomnost tutorů a studujících není nutná. Komunikace se realizuje pomocí elektronické pošty či diskusních fór).

Hlavními výhodami e-learningu jsou neomezený prístup $\mathrm{k}$ informacím, možnost pravidelné aktualizace informací, multimediálnost (oproti klasickým učebnicím může přispět $\mathrm{k}$ lepšímu pochopení probírané látky), interaktivita, verifikace (studující si může sám ověřit stupeň svých znalostí), individuální tempo samostudia.

$\mathrm{K}$ nevýhodám e-learningu patří to, že není vhodný pro každého (ne každý je schopen učit se z elektronických textů), není také vhodný pro takové oblasti vzdělávání, kde je nutná praktická zkušenost (medicína, rukodělné práce, ....) a kde není možné používat pouze e-learning. Omezující je také fakt, že realizace e-learningu je závislá na technologiích (je nutné mít multimediální počítač, připojení $\mathrm{k}$ síti, př́íslušné programy, což může být dost finančně náročné).

Vzory pro e-learning vznikly podobně jako pedagogické vzory. Jedná se o popisy typických situací, které musí řešit učitelé při použití e-learningového systému. Katalog vzorů lze najít např. na [11]. Tyto vzory lze použít nejen pro výuku samotnou, ale také např. pro hodnocení zvoleného e-learningového systému. Vzory totiž popisují, co všechno a jakým způsobem by měl či mohl takový systém zajišt'ovat. Katalog vzorů by v tomto prŕípadě mohl sloužit jako kontrolní seznam rysů systému.

Ke vzorům pro e-learning se řadí následující položky:

\section{Soubor studijních nástrojů}

Problém: Jak studujícím umožnit používat studijní prostředky místo omezení čtení 
jednoduchých HTML stránek?

Souvislosti: Studujícím dělá problémy číst studijní texty př́mo na obrazovce. Jsou zvyklí s textem dále pracovat: podtrhávat si barevně různé části textu, přeškrtávat nepotřebné věci, dopisovat si do textu poznámky. Toto však jednoduché HTML stránky neumožňují.

Řešení: Vytvořte soubor studijních nástrojů, které umožňují podtrhávat, přeškrtávat a barevně zvýrazňovat text, které umožňují do textu vkládat záložky, které umožňují vkládat do textu vlastní poznámky či otázky opatřené datem.

\section{Řizení skupin studujících}

Problém: Jak vytvářet a vést skupiny studujících a jak jim zadávat projekty?

Souvislosti: Jedním z nejobtížnějších úkolů e-learningu je vytváření vedení skupin studujících. Studující by měli být rozděleni do pracovních skupin, mělo by jim být umožněno komunikovat mezi sebou. Také by skupiny měly mít vyhrazené místo pro předávání výsledků skupinových projektů.

Řešení: Vytvořit nástroje, které umožňují vytvářet skupiny studujících (ručně i automaticky), umožňují členům skupin vzájemnou asynchronní (e-mail) i synchronní (chat) komunikaci, umožňují zadávat skupinám projekty, vyhradí skupinám prostor pro práci na projektech a umožñují jednoduché nahrávání a stahování rozpracovaných projektů. Přiřadit každé skupině supervisora - tutora, který se bude moci zapojit do diskuze se studujícími, bude se studenty řešit sporné problémy, bude hodnotit skupinové projekty.

\section{Řízení studentských úkolů}

Problém: Jak vytvářet on-line úkoly pro studující?

Souvislosti: Zadávání dotazů a cvičení studujícím je pro tutory velmi užitečné. e-learningové systémy by měly řešit, jak zadávat úkoly studujícím a jak je vyhodnocovat.

Řešení: Systém by měl poskytovat tutorovi nástroje $\mathrm{k}$ řízení úkolů: tutor by měl mít možnost definovat a zadávat úkoly. Každý úkol by měl kromě zadání obsahovat i odkazy na studijní materiály, datum odevzdání, studující by měl systém upozornit na nový úkol, systém by měl umožnit odevzdávání úkolů a jejich automatické přeposílání toturovi.

\section{Řízení on-line testů}

Problém: Jak vytvářet, zadávat a klasifikovat webové kvízy a testy?

Souvislosti: Důležitou činností je hodnocení získaných znalostí studujících. Jednou z nejčastějších metod jsou testy. Automatizace zadávání, vyplňování a hodnocení těchto testů umožňuje ušetřit lektorovi hodně času.

Řešení: Systém by měl lektorovi umožňovat vytvářet on-line testy $\mathrm{s}$ uzavřenou množinou odpovědí, vytvářet on-line testy $\mathrm{s}$ otevřenou množinou odpovědí, vytvářet a automaticky vyhodnocovat testy různých typů: pojmové dvojice, vyplňování prázdných míst apod., vytvářet pro lektora statistiku, kolikrát byl který test studujícím udělán, jaké jsou výsledky jednotlivých studujících, kolikrát byla určitá otázka správně a špatně zodpovězena apod., Měl by také umožňovat nastavit čas, po který test bude probíhat.

\section{Pedagogické antivzory}

Každý, kdo delší dobu učí, postupně zjištuje, jak mnoha a jak velkých chyb se dopustil. Je to přirozené, důležité však je, chyby neopakovat. $\mathrm{Na}$ stránkách Josepha Bergina (viz [2])) lze najít názvy vzorů, které velmi výstižně popisují to, co by učitelé neměli dělat. Tento seznam jakýchsi antivzorů může fungovat jako dobrá pomůcka pro učitele, kteří přemýšlejí o tom, proč se jim výuka nedaří. Jako př́klady uvádíme výstižná jména několika antivzorů: Ignoruj své studenty, Domácí úkol vrácený pozdě (nebo nikdy), Jediný způsob výuky (předpokládej, že to jak se učíš ty, je nejlepší i pro tvé studenty), Nepřipravuj se, Nikdy nebud' spontánní, Uč striktně v logickém pořadí, Moji studenti nejsou dost chytří, Jediná správná odpověd', Ignoruj studentovo zázemí.

\section{Mikrožánry}

On-line vzdělávání se od klasické výuky značně liší, a to nejenom co se týká nástrojů (tabuli a sešity nahradily počítače vybavené výkonnými programy a internetem), ale nastupují i nové výukové postupy. Metody používané při e-learningu jsou z části obdobné jako metody používané přri klasickém způsobu výuky. Při e-learningu je třeba tyto nástroje modifikovat vhledem $\mathrm{k}$ používaným technologiím. Pokusme se zmíněné komunikační prostředky analyzovat. Naše zkoumání se bude odvíjet od pojmu mikrožánr.

Se slovem žánr se určitě každý už setkal v souvislosti s uměleckými směry. Podle [4] je žánr rozdělení konkrétních forem umění na základě kritérií relevantních dané formě (např. filmový žánr, hudební žánr nebo literární žánr). Ve všech odvětvích umění jsou však žánry neurčité kategorie bez pevných hranic a jsou určeny především zažitými konvencemi. Mnoho děl pak jde např́íč několika žánry a používá 
a kombinuje tyto konvence. Snad nejhlouběji jsou teoreticky zkoumány žánry literární, protože to umožňuje systematizovat svět literatury a následně ho podrobit vědeckému zkoumání. Na tomto poli se také můžeme setkat s termínem mikrožánr. Například v [3] je mikrožánr chápán jako součást kombinovaného textu, kdy byl tento pojem zaveden za účelem identifikace, jak vložené žánry přispívají k celkové organizaci textu. Funkčně bylo tedy studium mikrožánrů motivováno snahou o vytvoření analytického popisného systému.

Termín mikrožánr se v současné době používá nejen v rétorice, literární teorii, teorii médií nebo lingvistice. Pojem mikrožánr se začal používat i v souvislosti s elektronickými texty (viz [3]) a také v souvislosti s novými pedagogickými technikami, které se váží k vyučování v prostředí počítačů (viz [5]).

K nejužívanějším mikrožánrům používaným ve výuce patř́ prezentace, diskuse, semináŕ, otázky a odpovědi, brainstorming, práce v malých skupinách. Jednotlivé mikrožánry je možné různě kombinovat. Pokud je posloupnost mikrožánrů vhodně zvolena, vede to ke zvýšení aktivity žáků a růstu jejich sebedůvěry ve vlastní schopnosti.

Nejprve, než se začneme zamýšlet nad realizací mikrožánrů v prostředí počítačů, je třeba si uvědomit, že nové vyučovací postupy lze budovat jen za předpokladu dostatečné počítačové gramotnosti žáků. Je také třeba vzít v úvahu, že nové neosobní technické zázemí poskytuje menší prostor pro spontánní přístup a že technická omezení mohou vytvářet mezi účastníky bariéry. Že on-line způsob vzdělávání klade vyšší nároky na prŕpravu učitelů i zodpovědnost a aktivní př́stup studentů.

Digitální realizace mikrožánrů se odvíjí od jejich tři základní atributů - obsahu, formy a funkce (srovnej [3]). Prostředí on-line vzdělávání nabízí uživateli řadu elementů, které lze použít při konstrukci digitálních stránek určených pro výuku. Patř́ k nim stylistické prvky (text, seznam, tabulka), barva, grafické prvky, možnost zajistit uživateli anonymní př́stup nebo vyžadovat jeho identifikaci, stanovit privilegia uživatelů, realizovat asynchronní a synchronní činnosti, nastavit čas pro synchronizaci. Standardní nástroje pro internetovou komunikaci umožňují jednotlivé akce strukturovat. To vytváří ideální prostor pro mikrožánry jako jsou

\section{Brainstorming}

Popis: Jedná se o volné fórum myšlenek a nápadů. Téma zadává a akci organizuje učitel.

Elektronická realizace: poznámky přicházejí mailem, jednotlivé ideje se mohou zobrazovat $\mathrm{v}$ tabulce, komentáře lze řadit do nesetř́íěného seznamu.

\section{Prezentace}

Popis: Slouží k uvedení do problematiky nebo k jejímu doplnění. Téma zadává učitel. Připravuje ji učitel nebo pověřený student.

\section{Elektronická realizace: pomocí} elektronického textu (popř. animací, audia, videa).

\section{Diskuse}

Popis: Dialog vedený mezi dvěma stranami, který má sloužit $\mathrm{k}$ utř́íbení a vyjasnění pojmů a závislostí mezi nimi. Řízení diskuse může mít v rukou učitel (formální debata) nebo může probíhat spontánně (neformální debata).

Elektronická realizace Realizovat lze pomocí e-mailu nebo přes Skype.

\section{Kvíz}

Popis: Dialog vedený mezi dvěma stranami, který má sloužit k utř́íbení a vyjasnění pojmů a závislostí mezi nimi. Řízení diskuse může mít v rukou učitel (formální debata) nebo může probíhat spontánně (neformální debata).

Elektronická realizace Realizovat lze pomocí e-mailu nebo přes Skype.

Schéma na Obr 1 znázorňuje, jakým způsobem je možné mikrožánry do výuky zařadit.

\section{Závěr}

V našem článku jsme se zabývali dvěma typy vzdělávacích metod založených jednak na pedagogických vzorech a jednak na mikrožánrech. Naším cílem bylo prezentovat trochu jiný př́stup $\mathrm{k}$ popisu metod, které lze úspěšně aplikovat ve vyučování. Př́istupy jsme převzali od autorů, kteří mají co do činění s počítačem podporovanou výukou. $\mathrm{Z}$ tohoto pohledu se uvedené př́istupy mohou jevit jako zjednodušující a poněkud technologické. Věříme však, že jako inspirace tyto postupy mohou dobře posloužit zejména těm učitelům, kteří nestudovali pedagogické disciplíny, a i presto chtějí mít jako učitelé dobré výsledky. Hodně se ted' také mluví o interaktivním způsobu výuky. $Z$ tohoto hlediska lze některé pedagogické vzory chápat jako návrh, jak tuto problematiku uchopit. 


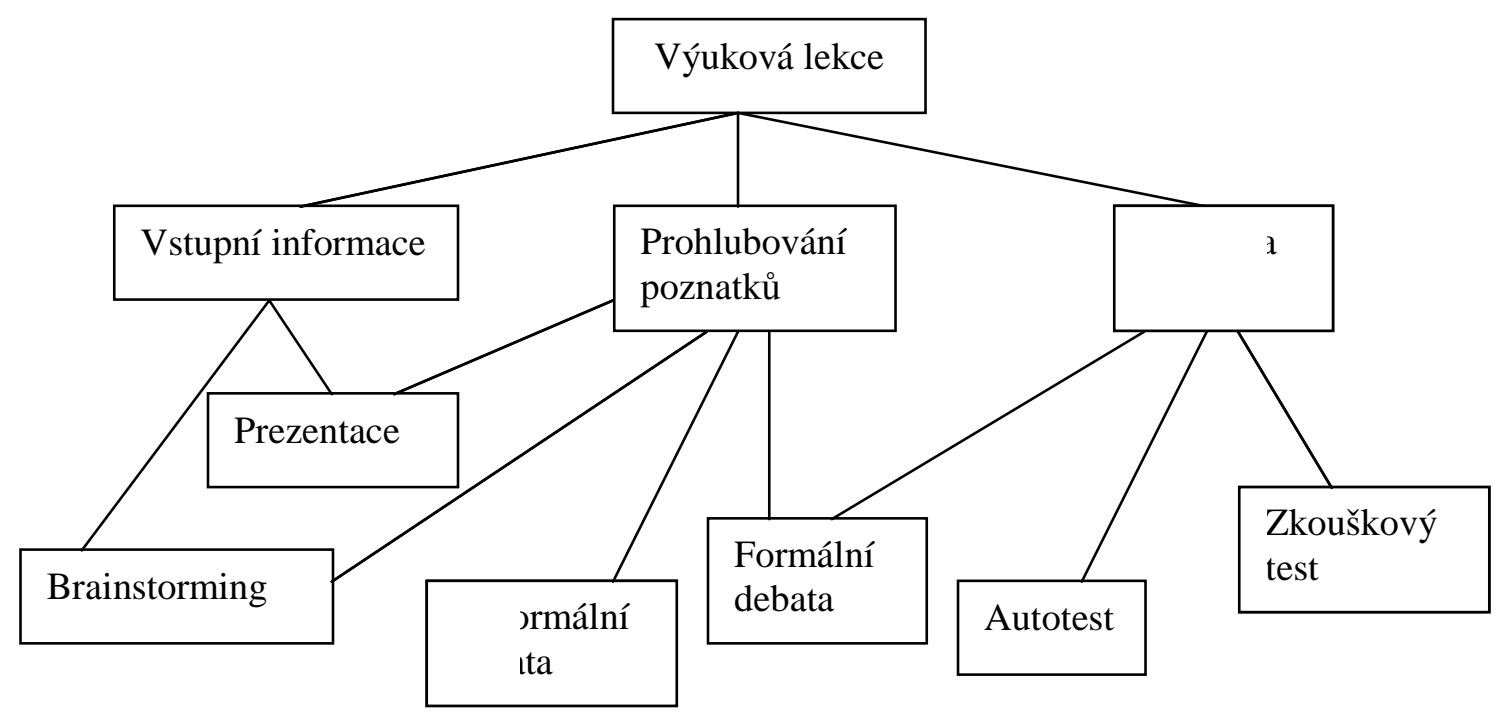

Obr.1: Zařazení mikrožánri̊ do výuky

\section{Literatura}

[1] ALEXANDER, CH. A. Pattern Language. New York. Oxford University Press 1977, ISBN 0195019199.

[2] BERGIN J. Joe Bergin's Wiki PedagogicalAntiPatterns (online). 2002 -2009 [cit. 2009-10-22]. URL:

<http://csis.pace.edu:8099/PedagogicalAntiPat terns>

[3] BREURE, L.: Development of the Genre Concept (online). 2001-2009 [cit. 2009-10-22]. URL:

<http://people.cs.uu.nl/leen/GenreDev/GenreD evelopment.htm>>

[4] Genre. Wikipedia (online). 2002-2009 [cit. 2009-10-22].

URL: <http://en.wikipedia.org/wiki/Genre>

[5] HUGHES, CH., HEWSON, L. Structuring Communication to Facilitate Effective Teaching and Learning. Computers in the Schools. 2001, vol 17, pp.147-158.

[6] KUDĚLKA, M., MOŠOVÁ, V. Vzory v komunikaci člověka s počítačem, sborník XXII. Vědeckého kolokvia o řízení osvojovacího procesu, VVŠ PV Vyškov 2004, ISBN 80-7231-116-6

[7] KUDĚLKA, M., MOŠOVÁ, V. Jak psát výukový text, sborník XXIV. Vědeckého kolokvia o řízení osvojovacího procesu, UO Brno 2006, ISBN 80-7231-139-5

[8] KUDĚLKA, M., MOŠOVÁ, V. Vizualizace - zdroj motivace, poučení a inspirace, sborník XXIV. Vědeckého kolokvia o řízení osvojovacího procesu, UO Brno 2006, ISBN 80-7231-139-5

[9] The Pedagogical Patterns Project (online). 2002 -2009 [cit. 2009-10-22]. URL:

$<$ http://www.pedagogicalpatterns.org>

[10] TIDWELL, J. Designing Interfaces: Patterns for Effective Interaction Design. O'Reilly Media, Inc. 2005. ISBN 0596008031.

[11] Towards a Pattern Language for

Learning Management Systems (online). 2003

-2009 [cit. 2009 -10-22]. URL:

<http://www.ifets.info/journals/6_2/2.html>

Mgr. Miloš Kudělka Ph.D.

FEI VŠB-TU Ostrava

17. listopadu 15, 70833 Ostrava - Poruba, ČR

Tel. +420 597325252

e-mail : kudelka@inflex.cz

RNDr. Vratislava Mošová CSc.

ÚEV MVŠO o.p.s.

Jeremenkova 42, 77200 Olomouc, ČR

tel. +420 587332312

e-mail: vratislava.mosova@mvso.cz 